\title{
A preliminary crown biomass table for even-aged Picea abies stands in Switzerland
}

\author{
V. A. USOLTSEV ${ }^{1}$ and C. W. HOFFMANN ${ }^{2}$
}

1 Russian Academy of Sciences, Forest Institute, Bilimbayevskaya 32a, Ekaterinburg 620134, Russia

2 Federal Institute of Forest, Snow and Landscape Research, CH-8903 Birmensdorf, Switzerland

\section{Summary}

The assessment of biomass and biomass changes due to environmental influences requires not only stem or merchantable mass, but also branches and needles. They have been of relatively little importance to forest managers to date, but their inclusion in models can make the resulting predictions more precise. A hybrid method is described to derive regressions for site quality, needle and branch biomass for individual Picea abies trees. By using Swiss stand table data on tree density distributions, a traditional yield table for branch and needle biomass is computed, and from these, regressions are derived which use only age and site quality as independent variables. Three tables for typical site qualities are given. The tabulated regressions include pseudoprobability values, coefficients of determination and estimated standard error for the overall models.

These biomass fractions comprise a varying fraction of the tree, being important at low ages and much less so at later ages.

\section{Introduction}

There are two main directions to forest biomass structure research: ecological, related to the organic matter and energy cycling in the forest ecosystem, and forest biomass estimation for utilization purposes. Traditional stem volume yield tables have played a major role in the latter approach, but there is no comparable information on the temporal development of other parts of a tree, namely the branches, foliage and different categories of roots. Studies of carbon cycling are shifting to the global level, and there Institute of Chartered Foresters, 1997 are a number of both national and international programmes related to carbon uptake by plants (Kurz et al., 1992; Kraeuchi, 1993; Nabuurs and Mohren, 1993). The development of methods to estimate the $\mathrm{C}$ pool and its annual turnover in forest biomass, involving about 70 per cent of the terrestrial carbon (Global BIOME Program, 1991), is therefore of interest. At present, the range of turnover estimates is extremely large, varying from 1 to $10 \mathrm{Gt} \mathrm{a}^{-1}$ on the global level (Global BIOME Program, 1991; Kraeuchi, 1993), and for the territory of the former Soviet 
Union between $200 \mathrm{Mt} \mathrm{a}^{-1}$ (Zavarzin, 1992; Isaev et al., 1993) and $4360 \mathrm{Mt} \mathrm{a}^{-1}$ (Kolchugina and Vinson, 1993). These discrepancies indicate a major need for the improvement of methods to estimate forest biomass and carbon budgets in terrestrial ecosystems.

Early descriptions of forest productivity include harvest biomass data per hectare together with stand indices (e.g. mean height, site index, age, stand density). There is a wealth of compilations of biomass for different forest stands (Rodin and Bazilevich, 1967; Madgwick, 1970; Utkin, 1970; Pozdnyakov, 1975; Stanek and State, 1978; Gholz et al., 1979; Reichle, 1981; Cannell, 1982; Valentine et al., 1984; Alaback, 1986, 1987; Wharton and Cunia, 1987; Palumets, 1991). Attempts to describe the multivariate structure of forest biomass variability have been made, resulting in linear regression equations of the form $\ln w_{i}=L$ (A, d.b.h., h, Z) (Usoltsev, 1983), or $\left(W_{i} / V\right)=L$ $(A, V, S)$ (Onuchin and Borisov, 1984). (Symbols are listed at the end of the paper.) The latter model has been used in forest biomass inventory, and acceptable results for total crown biomass have been achieved (Usoltsev, 1995). For other components, such as foliage and roots, it has been observed that the model can be improved by using $N$ and $D_{\mathrm{m}}$ instead of $V$ (Usoltsev, 1988b; Usoltsev and Hoffmann, 1997). Consequently, regression equations of the form:

$$
\ln \left(W_{i} / V\right)=L\left(A, S, D_{\mathrm{m}}, N\right),
$$

have been proposed (Usoltsev 1988a, b, 1995). A more recent method to estimate crown biomass exploits the pipe model (popularized by Shinozaki et al., 1964a, b) using the stem diameter just below the start of the crown d.b.c. (White, 1993). Its use is the subject of another paper (Usoltsev et al., 1997).

A large number of stand volume and yield tables has accumulated during the last 150 years of development of forest mensuration. Today, because of changing environmental conditions, less time-consuming methods for the estimation of analogous data for the other biomass compartments need to be adopted. In this paper, a method for combining traditional forest mensuration tables and models designed for stem volume with harvest biomass data is proposed. Unfortunately, root biomass could not be included, because there were no data available.
Yet another approach to describe the distribution of biomass within a tree is the process model approach. Here, physiological and other processes which determine forest production are formulated and combined into a model. Landsberg (1986) gives a basic set of equations governing weather influence, stand structure and microclimate, carbon balance of leaves of trees. nutrient dynamics and tree growth, and water relations, from the physiological point of view. Dixon (1990) discusses the main physiological processes from the modeler's point of view. Hierarchical and compartmentalized process models have been developed (e.g. Mitchell, 1975; Blake and Hoogenboom, 1988; Ford and Kiester, 1990; Bassow et al., 1990; Isebrands et al., 1990; Sievänen, 1993). Data for input consist of starting values of state variables, and of coefficients for the model equations which are estimated from process data, using mostly regression. This approach is not followed any further here, because stand tables cannot furnish these data.

\section{Materials and methods}

There are at least three major approaches to the problem of linking forest biomass data with yield table data. The first involves the use of recursive systems of regression equations (Amateis et al., 1984; Borders and Bailey, 1986; Borders, 1989; Usoltsev, 1988a, 1989, 1990), where the dependent variable of one of the equations becomes the independent variable in the others. Such a recursive system can be constructed by augmenting equation (1.1) by the linear regressions:

$$
\begin{gathered}
V=L(A, S) \\
N=L(A, S) \\
D_{\mathrm{m}}=L(A, S)
\end{gathered}
$$

and

$$
S=L\left(A, H_{\mathrm{m}}\right) .
$$

$S$ is used instead of mean height because of its wider use in yield tables and better predictive value.

Equations (1.1) to (1.3) were applied to aspen, birch, and stands of Pinus sylvestris L. in Northern Kazakhstan (Usoltsev, 1988b, 1989, 1990) and to stands of Picea abies and Pinus sylvestris 
in the Middle Urals (Usoltsev et al., 1994) where the qualities (1.2) and (1.3) were taken partly in analytical and partly in tabular form from yield tables. This approach rests on the assumption that stands with the same mean height, age, site index, mean diameter, tree density and stem volume agree in their distribution of biomass components.

The second approach is oriented to individual trees. It was suggested by Makarenko and Malenko (1984), and their biomass equations are of the form:

$$
{ }^{3} V_{w_{i}}=L\left(S, D_{\mathrm{m}} \text {, d.b.h., } h\right) .
$$

Makarenko et al. (1980) compiled yield tables for Pinus sylvestris stands in each of three regions of Northern Kazakhstan and described mathematically the age dynamics of the tree diameter distribution, also giving graphs of $h$ vs. d.b.h. Makarenko and Malenko (1984) constructed stand biomass tables by using (2) and the graphs of $h$ vs. d.b.h. The precision of these tables is roughly the same as that of the first approach, since it is assumed that two stands have the same biomass distribution if they have the same diameter distribution. This, however, is rather rare (Semechkina, 1978).

The third approach also uses biomass equations for individual trees, but does not take into account tree diameter distribution. Naturally, these estimates are less exact than those of the first two approaches, but they require less harvest biomass data. Root biomass tables for pine stands in Northern Kazakhstan of different age classes and ecological conditions were constructed in this manner (Usoltsev et al., 1985; Usoltsev and Vanclay, 1993):

$$
\ln w_{i}=(A, \text { d.b.h., } h) \text {. }
$$

To reach the stand level, equations (3) were modified as:

$$
\ln \left(W_{i} / N\right)=L\left(A, D_{\mathrm{m}}, H_{\mathrm{m}}\right)
$$

and developed into a recursive system of equations ((4.1) and (4.2) taken together):

$$
\begin{aligned}
N & =L(A, S) \\
D_{\mathrm{m}} & =L(A, S) \\
H_{\mathrm{m}} & =L(A, S),
\end{aligned}
$$

where equations (4.2) were taken in a tabular expression from yield tables.

\section{Results}

Burger (1953) published biomass data for 189 Norway spruce trees, from 15 to 285 years old, harvested in even-aged stands with different ecological conditions. These data include tree height, age and social status, but not site index or tree volume. Therefore, elements from all three approaches were used to compile biomass tables derived from the Swiss yield tables for even-aged spruce stands ([Badoux], 1983). As an approximation to the missing site index, following the first approach, a regression equation in the form of (1.3) was derived from the yield table. Inspection of the graphs of $\ln (S)$ vs. $\ln \left(H_{\mathrm{m}}\right)$ for constant $A$ (see Figure 1) suggested the inclusion of terms up to the second order. Backwards stepwise regression produced:

$\ln S=L\left(A, H_{\mathrm{m}}\right)=$

$a_{0}+a_{1}(\ln A)^{2}+a_{2}\left(\ln H_{\mathrm{m}}\right)^{2}+a_{3}(\ln A)\left(\ln H_{\mathrm{m}}\right)$ $+a_{4}(\ln A)^{2}\left(\ln H_{\mathrm{m}}\right)+a_{5}(\ln A)\left(\ln H_{\mathrm{m}}\right)^{2}+a_{6}$ $(\ln A)^{2}\left(\ln H_{\mathrm{m}}\right)^{2}$.

Coefficients and goodness of fit are shown in Table 1 . To eliminate the bias introduced by taking the logarithm of $S, a_{0}$ should be replaced by $a_{0}+(\text { s.d. })^{2} / 2$, following Finney (1941) and Baskerville (1972). This device is also recommended for equations (6) and (7). Based on the second approach, but using age instead of $S$ and $D_{\mathrm{m}}$ in (2), the following regression equations for branches and foliage dry mass were derived from Burger's data:

$\ln w_{i}=L(A$, d.b.h., $S)=$ $a_{0}+a_{1}(\ln A)+a_{2}(\ln$ d.b.h. $)+a_{3}(\ln A)$

$(\ln$ d.b.h. $)+a_{4} S+a_{5}(\ln S)+a_{6}(\ln v)$

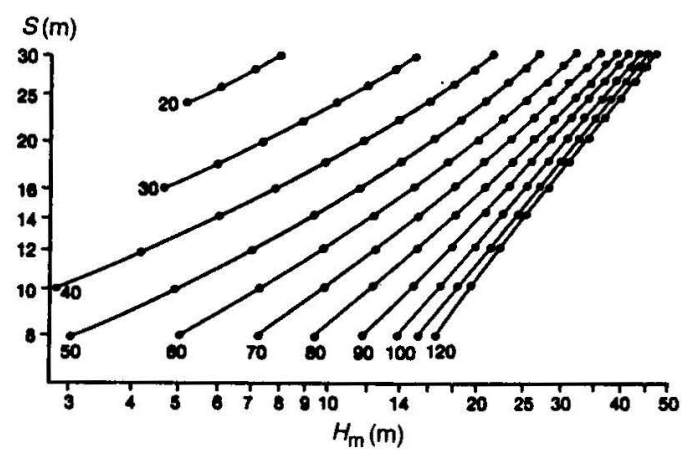

Figure 1. Relationship between site index $S$ and mean height $H_{\mathrm{m}}$ for different stand ages, labelled in years. 
Table 1: Regression coefficients and goodness of fit for equation (5) for site quality. Pseudoprobabilities for all coefficients are $<0.00015$

\begin{tabular}{cccccccccc}
\hline$a_{0}$ & $a_{1}$ & $a_{2}$ & $a_{3}$ & $a_{4}$ & $a_{5}$ & $a_{6}$ & $n$ & $R^{2}$ & s.d. \\
\hline 3.8172 & -0.1353 & 0.1332 & 0.2918 & -0.06253 & -0.1086 & 0.02527 & 131 & 0.997 & 0.0208 \\
\hline
\end{tabular}

Table 2: Coefficients and goodness of fit for equations (6) for dry biomass $(\mathrm{kg})$ of foliage and branches. All $a_{i}$ of foliage have $p<0.01$, those of branches have $p<0.00002$, except for $p\left(a_{4}\right)=$ $0.025, p\left(a_{5}\right)=0.039$, all $p^{*}<0.008$, except for $p\left(a_{2}\right)^{*}<0.047$

\begin{tabular}{lrrrrrrrrrr}
\hline & $a_{0}$ & $a_{1}$ & $a_{2}$ & $a_{3}$ & $a_{4}$ & $a_{5}$ & $a_{6}$ & $n$ & $R^{2}$ & s.d. \\
\hline $\ln \left(w_{\mathrm{f}}\right)$ & -0.8923 & -0.6451 & 2.2608 & - & -0.0460 & - & - & 168 & 0.888 & 0.3760 \\
$\ln \left(w_{\mathrm{b}}\right)$ & 0.8939 & -2.2271 & -1.5053 & 0.7733 & -0.1737 & 3.1575 & - & 161 & 0.888 & 0.3747 \\
$\ln \left(w_{\mathrm{b}}\right)^{*}$ & 9.8422 & -3.3238 & -1.4918 & 1.0899 & - & - & -0.4642 & 97 & 0.919 & 0.3124 \\
\hline
\end{tabular}

see Table 2. $(\ln v)$ is not significant in $\left(\ln w_{\mathrm{f}}\right)$, but if this term is included in $\left(\ln w_{\mathrm{b}}\right)$ (see line 3 labelled $\ln \left(w_{\mathrm{b}}\right)^{*}$ in Table 2), a slightly higher $R^{2}$ and a smaller s.d. are obtained than without this term. The use of $v$ became possible by retrieving the volumes from the original data records, but they were recorded for only 97 sample trees. Stem volume $v$ was not used in the subsequent computations for several reasons. First, too many of already scarce data would be lost without much gain. Second, sticking to the larger data set would tend to give better general predictions, against fitting a smaller set more precisely. Thus Table 3 was derived by applying (6) and using the coefficients of the first two lines of Table 2 to each diameter class and subsequent summation. Borrowing from the third approach (4), $S$ from (5) was used, generating from these tabulated data the relationship:

$\ln W_{i}=L(A, S)=$

$a_{0}+a_{1}(\ln A)+a_{2}(\ln A)^{2}+a_{3}(\ln A)^{3}+a_{4}(\ln$

$S)+a_{5}(\ln S)^{2}+a_{6}(\ln S)^{3}+a_{7}(\ln A)(\ln S)+a_{8}$ $(\ln A)(\ln S)^{2}+a_{9}(\ln A)^{2}(\ln S)+a_{10}(\ln A)^{2}(\ln$ $S)^{2}+a_{11}(\ln A)^{3}(\ln S)+a_{12}(\ln A)^{3}(\ln S)^{2}$.

for foliage and branches. The coefficients are given in Table 4 . In addition to the measured data, artificial data were introduced, using $W_{i}=$ $1, A=2$, at for every $S=8,10, \ldots 30$, to achieve reasonable extrapolation for ages less than the minimum age given in the yield table.
Equations (7) should not be used beyond ages $A$ greater than 120 years, because the yield tables only give tree densities up to this age.

\section{Discussion}

A very precise representation of site quality has been derived in (5). By adding s.d. ${ }^{2} / 2$ to the constant term, bias can be corrected. It can now be used wherever age and mean height are available. Although the stand tables were generated by visually smoothing growth data, the residuals of (5) show a reasonably normal behaviour, with only eight out of 131 deviating from normal at the tails.

The regressions (6) for branch and needle biomass of individual trees depend on d.b.h., age and site quality only. Following from the value of s.d. and because of the natural logarithm in (6), we get a relative error for predicting biomass of about 40 per cent. Thus, the entries of Table 3 should be seen as being precise to at most the first digit. They have not been rounded to one significant figure to avoid the introduction of another source of imprecision and to make it easier to assess their generation vis-à-vis future improvements. As can be seen from the tables, the foliage biomass for each site quality varies very little with age, showing a broad maximum in the middle of the age range. Within the range of prediction branch biomass 
drops to a minimum at about 50 years of age and rises from there with old age and site quality. The minimum of branch biomass with age varies with site quality and is highest for the medium site quality.

Although equation (6) suffers from a considerable lack of precision, it was decided to approximate the totals of Table 3 as precisely as these data permitted, arriving at equation (7) and Table 4, using age and site quality alone. Although Burger's data include trees older than 120 , (7) cannot be used for ages above 120 years, because stand table density data are lacking.

This material is preliminary. First, Burger's data were taken from experimental and some ad hoc plots. During the last 70 years ecological conditions may have changed, and with them, site index (Keller, 1978; Sennov, 1983). Consequently, there is a need to gather new field data. Second, root biomass distributions are also needed. Third, an attempt to obtain more tree volumes for Burger's original data should be made.

\section{Conclusions}

For carbon balance calculations there is a particular need of forest biomass tables which comprise more than stem volume. In this paper it is shown how recursive regression analysis can combine forest inventory data with biomass harvest data. Careful analysis of functional relationships can lead to good empirical formulae.

Although only a relatively small data set has been available, the results suggest that it is possible to estimate the biomass of foliage and branches from stand inventory data. However, uncertainties remain, which need to be resolved by collecting more data on the biomass of particular forest components, such as branches, leaves and needles, and most urgently, on roots. These are seldom considered in national forest inventories, but current changes in the requirements of such inventories mean that in the future, more data may be collected that are relevant to biomass estimation and the whole issue of carbon sequestration in forests.

Table 3: Dry biomass $\left(\mathrm{kg} \mathrm{ha}^{-1}\right)$ of foliage (first line) and of branches (second line), and tree density (ha ${ }^{-1}$, third line, from the yield table), according to site index, stand age, and diameter class $(\mathrm{cm})$. Bias correction applied (a) Site index $=14$

\begin{tabular}{|c|c|c|c|c|c|c|c|c|c|c|c|c|c|c|}
\hline \multirow[t]{2}{*}{ Age } & \multirow[b]{2}{*}{ Total } & \multicolumn{13}{|c|}{ Diameter class $(\mathrm{cm})$} \\
\hline & & 2 & 6 & 10 & 14 & 18 & 22 & 26 & 30 & 34 & 38 & 42 & 46 & 50 \\
\hline \multirow[t]{3}{*}{40} & 10480 & 27 & 1342 & 3387 & 5296 & 427 & & & & & & & & \\
\hline & 14484 & 177 & 3166 & 5010 & 5761 & 369 & & & & & & & & \\
\hline & 2894 & 268 & 1093 & 869 & 635 & 29 & & & & & & & & \\
\hline \multirow[t]{3}{*}{50} & 11200 & 3 & 565 & 1583 & 3828 & 3250 & 1766 & 205 & & & & & & \\
\hline & 13282 & 17 & 1275 & 2448 & 4613 & 3252 & 1522 & 156 & & & & & & \\
\hline & 1918 & 38 & 531 & 469 & 530 & 255 & 88 & 7 & & & & & & \\
\hline \multirow[t]{3}{*}{60} & 11461 & & 180 & 948 & 1823 & 3751 & 2747 & 1796 & 216 & & & & & \\
\hline & 13074 & & 391 & 1520 & 2389 & 4227 & 2744 & 1623 & 179 & & & & & \\
\hline & 1350 & & 190 & 316 & 284 & 331 & 154 & 69 & 6 & & & & & \\
\hline \multirow[t]{3}{*}{70} & 11420 & & 27 & 494 & 1035 & 2452 & 3731 & 2521 & 1075 & 86 & & & & \\
\hline & 13365 & & 56 & 817 & 1455 & 3056 & 4222 & 2633 & 1047 & 79 & & & & \\
\hline & 1003 & & 31 & 182 & 178 & 239 & 231 & 107 & 33 & 2 & & & & \\
\hline \multirow[t]{3}{*}{80} & 11358 & & 5 & 272 & 661 & 715 & 2549 & 3913 & 2479 & 714 & 51 & & & \\
\hline & 13871 & & 10 & 461 & 989 & 973 & 3213 & 4631 & 2780 & 763 & 52 & & & \\
\hline & 770 & & 6 & 109 & 124 & 76 & 172 & 181 & 83 & 18 & 1 & & & \\
\hline \multirow[t]{3}{*}{90} & 11167 & & & 115 & 386 & 558 & 1318 & 2665 & 2963 & 2205 & 898 & 59 & & \\
\hline & 14568 & & & 201 & 608 & 820 & 1828 & 3522 & 3758 & 2698 & 1064 & 68 & & \\
\hline & 608 & & & 50 & 78 & 64 & 96 & 133 & 107 & 60 & 19 & 1 & & \\
\hline \multirow[t]{3}{*}{100} & 10969 & & & 43 & 125 & 587 & 860 & 1497 & 2406 & 2643 & 1854 & 886 & 68 & \\
\hline & 15509 & & & 77 & 207 & 923 & 1298 & 2185 & 3408 & 3650 & 2503 & 1171 & 88 & \\
\hline & 495 & & & 20 & 27 & 72 & 67 & 80 & 93 & 77 & 42 & 16 & 1 & \\
\hline \multirow[t]{3}{*}{110} & 10621 & & & & 56 & 353 & 664 & 898 & 1654 & 2453 & 2574 & 1457 & 511 & \\
\hline & 16417 & & & & 98 & 590 & 1082 & 1432 & 2590 & 3779 & 3906 & 2183 & 757 & \\
\hline & 407 & & & & 13 & 46 & 55 & 51 & 68 & 76 & 62 & 28 & 8 & \\
\hline \multirow[t]{3}{*}{120} & 10246 & & & & & 217 & 536 & 632 & 897 & 1648 & 2237 & 2116 & 1451 & 511 \\
\hline & 17360 & & & & & 385 & 938 & 1095 & 1538 & 2804 & 3779 & 3552 & 2421 & 848 \\
\hline & 339 & & & & & 30 & 47 & 38 & 39 & 54 & 57 & 43 & 24 & 7 \\
\hline
\end{tabular}


(b) Site index $=20$

\begin{tabular}{|c|c|c|c|c|c|c|c|c|c|c|c|c|c|c|c|c|c|c|c|}
\hline Age & Total & \multicolumn{18}{|c|}{ Diameter class $(\mathrm{cm})$} \\
\hline \multirow[t]{2}{*}{30} & 10865 & 52 & 782 & 2393 & 3779 & 3860 & & & & & & & & & & & & & \\
\hline & 2708 & 556 & 697 & 672 & 496 & 287 & & & & & & & & & & & & & \\
\hline \multirow[t]{2}{*}{40} & 12256 & & 336 & 1402 & 2095 & 3519 & 3059 & 1667 & 177 & & & & & & & & & & \\
\hline & 16508 & & 1137 & 2972 & 3266 & 4361 & 3157 & 1477 & 138 & & & & & & & & & & \\
\hline 50 & 1167 & & 82 & 231 & 225 & 189 & 242 & 137 & 45 & 16 & & & & & & & & & \\
\hline \multirow[t]{3}{*}{60} & 12564 & & & 294 & 653 & 1109 & 1394 & 3140 & 3193 & 1557 & 931 & 292 & & & & & & & \\
\hline & 16514 & & & 675 & 1226 & 1792 & 1996 & 4067 & 3796 & 1717 & 961 & 284 & & & & & & & \\
\hline & 839 & & & 129 & 134 & 129 & 103 & 159 & 117 & 43 & 20 & 5 & & & & & & & \\
\hline \multirow[t]{3}{*}{70} & 12375 & & & 130 & 335 & 670 & 723 & 1180 & 2619 & 3148 & 2319 & 1057 & 195 & & & & & & \\
\hline & 17290 & & & 308 & 676 & 1196 & 1173 & 1766 & 3659 & 4141 & 2892 & 1257 & 222 & & & & & & \\
\hline & 630 & & & 63 & 76 & 86 & 59 & 66 & 106 & 96 & 55 & 20 & 3 & & & & & & \\
\hline 90 & 388 & & & & 23 & 27 & 42 & 34 & 41 & 53 & 56 & 47 & 33 & 20 & 11 & 1 & & & \\
\hline \multirow[t]{3}{*}{100} & 11582 & & & & 42 & 87 & 175 & 483 & 530 & 808 & 1306 & 1848 & 2012 & 1869 & 1334 & 784 & 304 & & \\
\hline & 21876 & & & & 100 & 195 & 379 & 1010 & 1076 & 1598 & 2527 & 3503 & 3743 & 3418 & 2402 & 1391 & 532 & & \\
\hline & 318 & & & & 12 & 14 & 18 & 34 & 27 & 31 & 39 & 44 & 39 & 30 & 18 & 9 & 3 & & \\
\hline \multirow[t]{3}{*}{110} & 11205 & & & & 13 & 41 & 73 & 294 & 388 & 514 & 913 & 1461 & 1698 & 1640 & 1534 & 1229 & 857 & 549 & \\
\hline & 23724 & & & & 33 & 98 & 171 & 672 & 870 & 1136 & 1987 & 3138 & 3603 & 3442 & 3186 & 2530 & 1749 & 1110 & \\
\hline & 263 & & & & 4 & 7 & 8 & 22 & 21 & 21 & 29 & 37 & 35 & 28 & 22 & 15 & 9 & 5 & \\
\hline \multirow[t]{3}{*}{120} & 10810 & & & & & 11 & 43 & 189 & 314 & 301 & 506 & 822 & 1238 & 1717 & 1714 & 1627 & 1261 & 830 & 237 \\
\hline & 25705 & & & & & 28 & 109 & 470 & 772 & 734 & 1226 & 1977 & 2962 & 4085 & 4057 & 3834 & 2959 & 1940 & 552 \\
\hline & 221 & & & & & 2 & 5 & 15 & 18 & 13 & 17 & 22 & 27 & 31 & 26 & 21 & 14 & 8 & 2 \\
\hline
\end{tabular}


(c) Site index $=26$

\begin{tabular}{|c|c|c|c|c|c|c|c|c|c|c|c|c|c|c|c|c|c|c|c|c|c|c|c|}
\hline \multirow[t]{2}{*}{ Age } & \multirow[b]{2}{*}{ Total } & \multicolumn{22}{|c|}{ Diameter class $(\mathrm{cm})$} \\
\hline & & 2 & 6 & 10 & 14 & 18 & 22 & 26 & 30 & 34 & 38 & 42 & 46 & 50 & 54 & 58 & 62 & 66 & 70 & 74 & 78 & 82 & 86 \\
\hline \multirow[t]{3}{*}{20} & 10251 & 100 & 1306 & 1930 & 2028 & 3009 & 1878 & & & & & & & & & & & & & & & & \\
\hline & 17352 & 2023 & 5385 & 3795 & 2448 & 2524 & 1177 & & & & & & & & & & & & & & & & \\
\hline & 3400 & 1082 & 1181 & 550 & 270 & 227 & 90 & & & & & & & & & & & & & & & & \\
\hline \multirow[t]{3}{*}{30} & 12070 & 6 & 370 & 1227 & 2145 & 1949 & 3373 & 2179 & 777 & 43 & & & & & & & & & & & & & \\
\hline & 14362 & 86 & 1410 & 2614 & 3119 & 2130 & 2935 & 1569 & 476 & 23 & & & & & & & & & & & & & \\
\hline & 1870 & 91 & 435 & 454 & 371 & 191 & 210 & 93 & 24 & 1 & & & & & & & & & & & & & \\
\hline \multirow[t]{3}{*}{40} & 12515 & & 20 & 516 & 1253 & 2238 & 1868 & 2803 & 2394 & 964 & 459 & & & & & & & & & & & & \\
\hline & 13957 & & 71 & 1165 & 2080 & 2951 & 2051 & 2642 & 1980 & 711 & 306 & & & & & & & & & & & & \\
\hline & 1193 & & 28 & 230 & 261 & 264 & 140 & 144 & 89 & 27 & 10 & & & & & & & & & & & & \\
\hline \multirow[t]{3}{*}{50} & 12484 & & & 136 & 453 & 1050 & 1548 & 2073 & 2609 & 2071 & 1351 & 947 & 245 & & & & & & & & & & \\
\hline & 14043 & & & 321 & 833 & 1602 & 2036 & 2409 & 2726 & 1973 & 1185 & 771 & 186 & & & & & & & & & & \\
\hline & 815 & & & 70 & 109 & 143 & 134 & 123 & 112 & 67 & 34 & 19 & 4 & & & & & & & & & & \\
\hline \multirow[t]{3}{*}{60} & 12258 & & & 33 & 170 & 411 & 822 & 1064 & 1636 & 2831 & 2332 & 1640 & 925 & 394 & & & & & & & & & \\
\hline & 14766 & & & 80 & 340 & 707 & 1252 & 1467 & 2070 & 3322 & 2561 & 1695 & 906 & 367 & & & & & & & & & \\
\hline & 587 & & & 19 & 46 & 63 & 80 & 71 & 79 & 103 & 66 & 37 & 17 & 6 & & & & & & & & & \\
\hline \multirow[t]{3}{*}{70} & 11984 & & & & 90 & 183 & 409 & 610 & 712 & 1567 & 2304 & 2367 & 1675 & 1012 & 637 & 416 & & & & & & & \\
\hline & 15896 & & & & 194 & 348 & 706 & 972 & 1059 & 2195 & 3057 & 2994 & 2029 & 1177 & 714 & 451 & & & & & & & \\
\hline & 444 & & & & 27 & 31 & 44 & 45 & 38 & 63 & 72 & 59 & 34 & 17 & 9 & 5 & & & & & & & \\
\hline \multirow[t]{3}{*}{80} & 11764 & & & & 43 & 98 & 171 & 448 & 413 & 548 & 1115 & 1656 & 2170 & 1856 & 1364 & 1069 & 710 & 102 & & & & & \\
\hline & 17402 & & & & 98 & 202 & 328 & 809 & 706 & 894 & 1745 & 2495 & 3159 & 2618 & 1869 & 1426 & 924 & 130 & & & & & \\
\hline & 345 & & & & 14 & 18 & 20 & 36 & 24 & 24 & 38 & 45 & 48 & 34 & 21 & 14 & 8 & 1 & & & & & \\
\hline \multirow[t]{3}{*}{90} & 11214 & & & & & 60 & 95 & 242 & 383 & 508 & 626 & 682 & 1215 & 1670 & 1667 & 1415 & 1152 & 758 & 541 & & & & \\
\hline & 18838 & & & & & 135 & 201 & 488 & 740 & 948 & 1132 & 1199 & 2081 & 2791 & 3052 & 2268 & 1811 & 1171 & 822 & & & & \\
\hline & 276 & & & & & 12 & 12 & 21 & 24 & 24 & 23 & 20 & 29 & 33 & 31 & 20 & 14 & 8 & 5 & & & & \\
\hline \multirow[t]{3}{*}{100} & 10942 & & & & & 28 & 44 & 75 & 164 & 296 & 483 & 542 & 861 & 1324 & 1519 & 1521 & 1307 & 1151 & 809 & 688 & 129 & & \\
\hline & 20951 & & & & & 68 & 102 & 168 & 354 & 625 & 994 & 1093 & 1705 & 2576 & 2910 & 2871 & 2434 & 2117 & 1470 & 1236 & 230 & & \\
\hline & 226 & & & & & 6 & 6 & 7 & 11 & 15 & 19 & 17 & 22 & 28 & 27 & 23 & 17 & 13 & 8 & 6 & 1 & & \\
\hline \multirow[t]{3}{*}{110} & 10597 & & & & & & 28 & 51 & 70 & 167 & 287 & 450 & 515 & 845 & 1058 & 1492 & 1301 & 1166 & 1046 & 863 & 850 & 408 & \\
\hline & 23148 & & & & & & 69 & 123 & 167 & 393 & 664 & 1027 & 1164 & 1886 & 2339 & 3268 & 2825 & 2510 & 2236 & 1830 & 1791 & 854 & \\
\hline & 188 & & & & & & 4 & 5 & 5 & 9 & 12 & 15 & 14 & 19 & 20 & 24 & 18 & 14 & 11 & 8 & 7 & 3 & \\
\hline \multirow[t]{3}{*}{120} & 10505 & & & & & & & 19 & 40 & 141 & 407 & 255 & 383 & 420 & 600 & 941 & 1367 & 1338 & 1169 & 1020 & 919 & 772 & 716 \\
\hline & 26194 & & & & & & & 51 & 104 & 365 & 1048 & 653 & 975 & 1064 & 1512 & 2359 & 3414 & 3329 & 2897 & 2518 & 2261 & 1893 & 1751 \\
\hline & 168 & & & & & & & 2 & 3 & 8 & 18 & 9 & 11 & 10 & 12 & 16 & 20 & 17 & 13 & 10 & 8 & 6 & 5 \\
\hline
\end{tabular}


Table 4: Coefficients and goodness of fit of equation (7) for dry biomass ( $\mathrm{kg}$ ) of foliage and branches $\left(\mathrm{t} \mathrm{ha}^{-1}\right)$. All $a_{i}$ of foliage have $p<0.0002$, those of branches have $p<0.016$, except for $p\left(a_{6}\right)=0.079, p\left(a_{12}\right)=0.145$

\begin{tabular}{|c|c|c|c|c|c|c|c|c|}
\hline & $a_{0}$ & $a_{1}$ & $a_{2}$ & $a_{3}$ & $a_{4}$ & $a_{5}$ & $a_{6}$ & $a_{7}$ \\
\hline $\ln \left(W_{f}\right)$ & 7.0126 & -6.6481 & 3.2511 & -0.3633 & -8.0522 & 1.7832 & -0.1890 & 6.8172 \\
\hline \multirow[t]{2}{*}{$\ln \left(W_{b}\right)$} & 6.7973 & -1.7212 & - & 0.0535 & -12.0978 & 3.1221 & -0.2793 & 9.8377 \\
\hline & $a_{8}$ & $a_{9}$ & $a_{10}$ & $a_{11}$ & $a_{12}$ & $n$ & $R^{2}$ & s.d. \\
\hline $\ln \left(W_{f}\right)$ & -0.3544 & -2.0172 & 0.0484 & 0.1785 & - & 130 & 1.000 & 0.0219 \\
\hline $\ln \left(W_{b}\right)$ & -1.3199 & -2.0897 & 0.2016 & 0.1201 & $-7.802 * 10^{-6}$ & 130 & 1.000 & 0.0400 \\
\hline
\end{tabular}

\section{Acknowledgements}

We thank John Innes, Paul Schmid-Haas, and Andreas Zingg for their valuable comments and help.

\section{List of symbols}

\section{$A \quad$ age of tree (years)}

$a_{i} \quad$ coefficients of regression equations

d.b.c. stem diameter just below the start of the crown $(\mathrm{cm})$.

d.b.h. stem diameter at breast height $(\mathrm{cm})$.

$D_{\mathrm{m}} \quad$ mean diameter at breast height $(\mathrm{cm})=$ $\left(\Sigma\right.$ b.h.d. $\left.{ }_{i}\right) / n$, summed over the stand

$b$ tree height $(\mathrm{m})$

$H_{\mathrm{m}} \quad$ stand mean height $(\mathrm{m})$

$L$ polynomial of arguments in following brackets and of logarithms of these arguments

In natural logarithm

$n$ number of data points used in analysis

$N$ tree density $\left(\mathrm{ha}^{-1}\right)$

$p \quad$ probability of regression coefficient

$R^{2} \quad$ coefficient of determination of an estimated model

s.d. estimated standard deviation of residuals

$S \quad$ site index, i.e. height of 100 thickest trees (on $1 \mathrm{ha}$ ) at age 50 years $(\mathrm{m})$

$v \quad$ stem volume $\left(\mathrm{dm}^{3}\right)$

$V \quad$ stem volume $\left(\mathrm{m}^{3} \mathrm{ha}^{-1}\right)$

$w_{i} \quad$ dry biomass (subscripts: $\mathrm{b}=$ branches, $\mathrm{f}$ $=$ foliage) for a tree $(\mathrm{kg})$

$W_{i} \quad$ dry biomass (subscripts: $\mathrm{b}=$ branches, $\mathrm{f}$ $=$ foliage $)$ for a stand $\left(\mathrm{tha}^{-1}\right)$

$Z \quad$ stem density $\left(\right.$ ha $\left.^{-1}\right)$ divided by the stem density taken from a corresponding yield table

\section{References}

Alaback, P.B. 1986 Biomass regression equations for understory plants in coastal Alaska, effects of species and sampling design on estimates. Northwest Sci. 60(2), 90-103.

Alaback, P.B. 1987 Biomass-dimension relationships of understory vegetation in relation to site and stand age. In Estimating Tree Biomass Regressions and their Error, Proc. Workshop on Tree Biomass Regression Functions and their Contribution to Error of Forestry Inventory Estimates, 1986. May, 26-30, Syracuse, NY. NE-GTR-117, Broomall, PA, US Dep. Agr., p. 141-148.

Amateis, R.L., Burkhart, H.E., Greber, B.J., Watson, E.E. 1984 A comparison of approaches for predicting multi-product yields from weight-scaling data. For. Sci. 30(4), 991-998.

[Badoux, E.] 1983 Ertragstafeln Fichte. Eidg. Anst. für das forstl. Versuchswesen, Birmensdorf.

Baskerville, G.L. 1972 Use of logarithmic regression in the estimation of plant biomass. Can. J. For. Res. 2, 49-53.

Bassow, S.L., Ford, E.D., Kiester, A.R. 1990 A critique of carbon-based tree growth models. In Process Modeling of Forest Growth Responses to Environmental Stress. R.K. Dixon et al. (eds). Timber Press, Portland, OR, 50-57.

Blake, J.I. and Hoogenboom, G. 1988 A dynamic simulation of loblolly pine (Pinus taeda L.) seedling establishment based upon carbon and water balances. Can. J. For. Res. 18(7), 833-850.

Borders, B.E. 1989 Systems of equations in forest stand modelling. For. Sci., 35(2), 548-556.

Borders, B.E. and Bailey, R.L. 1986 A compatible system of growth and yield equations for slash pine fitted with restricted three-stage least squares. For. Sci. 32(1), 185-201.

Burger, H. 1953 Holz, Blattmenge und Zuwachs. 13. Mitteilung: Fichten in gleichaltrigen Hochwald. 
Mitt. Schweiz. Anstalt Forstl. Versuchswesen, 29, 38-130.

Cannell, M.G.R. (compiler) 1982 World Forest Biomass and Primary Production Data. Academic Press, London.

Dixon, R.K. 1990 Physiological processes and tree growth. In Process Modeling of Forest Growth Responses to Environmental Stress. R.K. Dixon et al. (eds). Timber Press, Portland, OR, 21-23.

Finney, D.J. 1941 On the distribution of a variable whose logarithm is normally distributed. J.R. Stat. Soc. B7, 155-161.

Ford, E.D. and Kiester, A.R. 1990 Modeling the effects of pollutants on the processes of tree growth. In Process Modeling of Forest Growth Responses to Environmental Stress. R.K. Dixon et al. (eds). Timber Press, Portland, OR, 324-337.

Gholz, H.L., Grier, C.C., Campbell, A.G., Brown, A.T. 1979 Equations for Estimating Biomass and Leaf Area of Plants in the Pacific Northwest. Res. Pap. 41. Corvallis, OR, Oregon State Univ., School of Forestry, 39pp.

Global BIOME Program. 1991 U.S. Environ. Protection Agency, Corvallis 8 pp.

Isaev, A.S., Korovin, G.N., Utkin, A.I., Pryazhnikov, A.A., Zamolodchikov, D.G. 1993 Estimation of carbon pool and its annual deposition in phytomass of forest ecosystems in Russia. Soviet Forest Sci. (Lesovedenie), 5, 1-7.

Isebrands, J.G., Rauscher, H.M., Crow, T.R., Dickmann, D.I. 1990 Whole-tree growth process models based on structural-functional relationships. In Process Modeling of Forest Growth Responses to Environmental Stress. R.K. Dixon et al. (eds). Timber Press, Portland, OR, 96-112.

Keller, W. 1978 Einfacher ertragskundlicher Bonitätsschlüssel für Waldbestände in der Schweiz. Eidg. Anst. Forstl. Versuchswes., Mitt. 54(1), 3-98.

Kolchugina, T.P. and Vinson, T.S. 1993 Equilibrium analysis of carbon pools and fluxes of forest biomes in the former Soviet Union. Can. J. For. Res. 23, 81-88.

Kraeuchi, N. 1993 Climate change and forest ecosystems - An overview. In Long term Implications of Climate Change and Air Pollution on Forest Ecosystems. R. Schlaepfer (ed.). Progress Report of the IUFRO Task Force 'Forest, Climate Change and Air Pollution'. Vienna, IUFRO; Birmensdorf, WSL. IUFRO World Series, Vol 4: 53-76.

Kurz, W.A., Apps, M.J., Webb, T.M., McNamee, P.J. 1992 The carbon budget of the Canadian forest sector: Phase 1. Forestry Canada, Inf. Rep. NOR-X-326. 93 pp.

Landsberg, J.J. 1986 Physiological Ecology of Forest Production. Academic Press, London, 198 pp.

Madgwick, H.A.I. 1970 Biomass and productivity models of forest canopies. In Ecological Studies: Analysis of Temperate Forests, Vol 1. D.E. Reichle (ed.). Berlin 47-54.

Makarenko, A.A., Lagunov, P.M., Kharitonov, B.E., Shevchuk, E.I., Krichun, V.M., Tokmurzin, T.Kh. 1980 Spravochnik po taksatsii lesov Kazakhstana. (Forest Inventory Handbook of Kazakhstan.) Kainar, Alma-Ata, 313 pp. (in Russian).

Makarenko, A.A. and Malenko, A.A. 1984 Struktura fitomassy molodnyakov sosny lentochnikh borov Kazakhstana. (Biomass, structure of young pine stands in the banded pine forests of Kazakhstan.) Vestn. S-Kh. Nauki Kazakhstana 6, 79-82 (in Russian).

Mitchell, K. 1975 Dynamics and simulated yield for Douglas-fir. Forest Science Monograph No 17. American Society of Foresters, Washington DC.

Nabuurs, G.J. and Mohren, G.M.J. 1993 Carbon fixation through forestation activities. IBN Res. Rep. 93/4. IBN-DLO, FACE. Netherlands, Wageningen, Arnhem, 205 pp.

Onuchin, A.A. and Borisov, A.N. 1984 Opyt taksatsii fitomassy sosnovikh drevostoev. (Trial in measuring the phytomass of Scots pine stands.) Lesovedenie 6, 66-71 (in Russian).

Palumets, Ya. K. 1991 Analysis of phytomass partitioning in Norway spruce. VIII Scripta Botanica. Tartu Uelikool, Tartu, pp. 95.

Pozdnyakov, L.K. 1975 Produktivnost lesov Sibiri (Productivity of Siberian forests). In Resursy biosfery, Vypusk 1. (Biosphere Resources. Issue 1.) Leningrad, Nauka, 43-55 (in Russian).

Reichle, D.E. 1981 Dynamic Properties of Forest Ecosystems. International Biological Programme 23. Cambridge University Press, Cambridge.

Rodin, L.E. and Bazilevich, N.I. 1967 Production and Mineral Cycling in Terrestrial Vegetation. Oliver and Boyd, Edinburgh and London, $288 \mathrm{pp}$.

Semechkina, M.G. 1978 Struktura fitomassy sosnyakov. (Phytomass structure in Scots pine (Pinus sylvestris $L$.)) Novosibirsk, Nauka (in Russian).

Sennov, S.N. 1983 O metodike modelirovanya proisveditelnosti. Modelirovanye $i$ kontrol proisveditelnosti drevostoyev. (On the methods of forest yield modelling. In Modelling and Control of Forest Stand Yield.) Kaunas-Academy, Lithuania, 44-46. (in Russian).

Shinozaki, K., Yoda, K., Hozumi, K. and Kira, T. 1964a A quantitative analysis of plant form the pipe model theory. 1: Basic analysis. Japan. J. Ecol. 14(3), 97-105.

Shinozaki, K., Yoda, K., Hozumi, K. and Kira, T. 1964b A quantitative analysis of plant form the pipe model theory. 2: Further evidence of the theory and its application in forest ecology. Japan. J. Ecol. 14(3), 133-139. 
Sievänen, R. 1993 A process-based model for the dimensional growth of even-aged stands. Scand. J. For. Res. 8, 28-48.

Stanek, W. and State, D. 1978 Equations Predicting Primary Productivity (Biomass) of Trees, Shrubs and Lesser Vegetation Based on Current Literature. Can. For. Service, Pacific Forest Res. Centre, Victoria, B.C., 58 pp.

Usoltsev, V.A., 1983 Prognozirovanye biologicheskoi produktivnosti beryosy $\mathrm{i}$ ociny $\mathrm{v}$ kolochnikh lesakh. (Predicting biological productivity of birch and aspen island-like forests.) Vestnik S. $K h$. Nauki Kazakhstana 6, 69-77 (in Russian).

Usoltsev, V.A. 1988a Principles and methods of compiling stand bioproductivity. Soviet Forest Sciences (Lesovedenie), Allerton Press Inc. 2, 23-32.

Usoltsev, V.A. 1988b Rost i Struktura Fitomassy Drevostoev. (Growth and Structure of Forest Stand Biomass.) Novosibirsk, Nauka (in Russian).

Usoltsev, V.A. 1989 Recurrent regression system as a base for tree and stand biomass tables. In Harvesting and utilization of tree foliage. IUFRO Project Group P3.05-00 Meeting, Riga, 217-245.

Usoltsev, V.A. 1990 Mensuration of forest biomass: Modernisation of standard base of forest inventory. In XIX World Congress Proceedings. IUFRO, Division 4. Montreal, Canada, 79-92.

Usoltsev, V.A. 1995 Mezhdunarodny lesnoi monitoring, globalnye ekologicheskie programmy i basy dannykh o fitomasse lesov. (International forest biomass monitoring, global ecological programs and forest biomass databases.) Lesnoye Khozyaistvo (Forest Management) 5: 33-35 (in Russian).

Usoltsev, V.A. and Hoffmann, C.W. 1997 Combining harvest sample data with inventory data to estimate forest biomass. Scand. J. For. Res (in press).

Usoltsev, V.A. and Vanclay, J.K. 1993 Biomass growth and structure of pine plantations and natural forests on dry steppe in Kazakhstan. In Growth and Yield Estimation from Successive Forest Inventories. Proc. IUFRO Conference. Forskningsserien, 3, 267-281.
Usoltsev, V.A., Krepki, I.S. and Prokhorov, Yu.A. 1985 Biologicheskaya produktivnost estestvennikh i iskustvennikh sosnyakov Aman-Karagaiskovo bora. (Biological productivity of pine plantations and natural stands in Aman-Karagai forest.) Vestn. S-Kh. Nauki Kazakbstana 8, 74-79 (in Russian).

Usoltsev, V.A., Melnikova, I.V., Tepikin, S.V. and Nagimov, Z.Ya. 1994 Khod rosta nadzemnoi fitomassy sosnyakov i elnikov Srednevo Urala. (Above ground phytomass yield tables for Scots pine and Norway spruce in the Middle Urals.) In Lesa Urala $i$ Khozyaistvo $v$ Nikh. (The Urals forests and their Management.) 17, Ekaterinburg (in Russian).

Usoltsev, V.A., Hoffmann, C.W., Melnikova, I.V., Tepikin, S.V., Salnikov, A.A., Kirillova, V.V. et al. 1997 Tree-crown biomass estimation in five forest species of the Urals and of Kazakhstan. (in preparation).

Utkin, A.I. 1970 Issledovania po pervichnoi biologicheskoi produktivnosti lessov v SSSR. (Studying the primary biological productivity of the USSR forests.) Lesovedenie 3, 58-89 (in Russian).

Valentine, H.T., Tritton, L.M. and Furnival, G.M. 1984 Subsampling trees for biomass, volume, or mineral content. For. Sci. 30(3), 673-681.

Wharton, E.H. and Cunia, T. 1987 Estimating tree biomass regressions and their error. Proc. Workshop on Tree Biomass Regression Functions and their contribution to Error of Forestry Inventory Estimates, 1986. May 26-30, Syracuse, NY. NE-GTR-117, Broomall, PA, US Dep. Agr. 303 pp.

White, D.A. 1993 Relatonships between foliar number and the cross-sectional areas of sapwood and annual rings in red oak (Quercus rubra) crowns. Can. J. For. Res. 23, 1245-1251.

Zavarzin, G.A. 1992 Mezhdunarodnoye ekologicheskie konventsii. (International ecological conventions.) Nature (Priroda) 12, 3-7 (in Russian).

Received 4 April 1996 